\title{
Konrad Cimachowicz
}

University of Lodz, Poland

ORCID: 0000-0003-4608-3967

cimachowicz@interia.pl

\section{Some Remarks on the Criminal Liability of Slaves Based on Lex Iulia de adulteriis coercendis}

\author{
Kilka uwag o odpowiedzialności karnej niewolników na gruncie Lex \\ lulia de adulteriis coercendis
}

\begin{abstract}
The purpose of this article is to attempt to answer the question whether a slave or female slave were criminally responsible for adultery. The Lex Iulia de adulteriis coercendis promulgated in 18 B.C., belonged to the so-called Augustan marriage legislation, introduced the term adulterium understood as a crime of public law. This law was very widely commented on by Roman jurists. However, the opposite views on the criminal liability of slaves under this statute are noticed in accessible legal sources. In the literature devoted to the Julian Act, this issue has not been sufficiently analyzed.
\end{abstract}

Keywords: criminal responsibility; public law; Lex Iulia de adulteriis coercendis; crimina legitima; slave; female slave

\section{INTRODUCTION}

The statute Iulia de Adulteriis Coercendis was promulgated in 18 B.C. and was aimed to penalize socially unacceptable sexual relations, as well as behaviours related to adultery and fornication. This statute repealed the existing regulations in this area and it introduced the concepts of adultery and stuprum, recognizing these actions as public crimes. The reasons for the introduction of lex Iulia that belongs

CORRESPONDENCE ADDRESS: Konrad Cimachowicz, PhD Student, University of Lodz, Faculty of Law and Administration, Kopcińskiego 8/12, 90-232 Lodz, Poland. 
to the so-called Augustan marriage laws were multiple. Among them, the literature indicates, i.a., the wish to stop the progress of demoralization and the determination to restore the customs of ancestors that have been forgotten. ${ }^{1}$

\section{ANALYSIS}

The provisions of the statute Iulia de adulteriis coercendis focus on the concepts of adulterium and stuprum. However, the available sources do not contain legal definitions of these concepts. They are not even found in the Digest, where the entire fifth title of the $48^{\text {th }}$ Book was dedicated to these subjects. This may be the result of the widespread reluctance of the Roman jurists to define concepts and institutions, or possible failure to comply with the definitions in juridical sources related to the statute. Papinian's statement may be helpful one in defining the terms adulterium and stuprum:

D. 48.5.6.1: Papinianus libro primo de adulteriis: Lex stuprum et adulterium promiscui et kataxrystikwteron appellat. sed proprie adulterium in nupta committitur, propter partum ex altero conceptum composito nomine: stuprum vero in virginem viduamve committitur, quod graeci fvoran appellant. $^{2}$

The above-quoated fragment of the Digest was commented by D. Stolarek, ${ }^{3}$ which indicates that the distinction made by Papinian is not accurate. She also suggests that perhaps the jurist was aware that the distinction between married and unmarried women is not a sufficient criterion for determining the subjective scope of particular type of adultery. In her opinion "it is also possible that the term

1 M. Zabłocka, Zmiany w ustawach małżeńskich Augusta za panowania dynastii julijsko-klaudyjskiej, „Prawo Kanoniczne” 1987, no. 1-2, pp. 151-178. See H. Kowalski, Omnia sunt alia non crimina, sed maledicta - oskarżenia o nieobyczajność w rzymskich procesach karnych pierwszej połowy I wieku p.n.e. (na podstawie mów Cycerona), [in:] Contra leges et bonos mores. Przestepstwa obyczajowe w starożytnej Grecji i Rzymie, eds. H. Kowalski, M. Kuryłowicz, Lublin 2005, pp. 161-172; T.A.J. McGinn, Concubinage and the Lex Iulia on Adultery, "Transactions of the American Philological Association" 1991, vol. 121, p. 340; R. Langlands, Sexual Morality in Ancient Rome, New York 2006, p. 20.

2 "Papinian, Adulterers, Book 1: The law refers to stuprum and adultery indiscriminately and with rather a misuse of terms. But properly speaking adultery is committed with a married woman, the name being derived from children conceived by another (alter); stuprum, however, is committed against a virgin or a widow; the Greeks call it corruption". Translation of the cited excerpts from Digests was given after the English edition: The Digest of Justinian, transl. A. Watson, Philadelphia 1985.

D. Stolarek, Ustawa julijska o karaniu za cudzołóstwa 5 tytuł 48 księgi Digestów. Tekst, tlumaczenie, komentarz, „Zeszyty Prawnicze” 2012, no. 12.1, pp. 205-224. See G. Rizzelli, Stuprum e adulterium nella cultura augustea e la lex Iulia de adulteriis (Pap. 1 adult. D. 48.5.6.1 e Mod. 9 diff. D.50.16.101 pr.), "Bullettino dell'istituto di Diritto Romano" 1987, no. 90, p. 357. 
stuprum was used in a broad sense to describe abusive behaviour, which would justify the jurist's remark about terminological inaccuracies". ${ }^{4}$ This observation is confirmed by Modestinus' testimony:

D. 50.16.101 pr:: Modestinus libro nono differentiarum: Inter "stuprum" et "adulterium" hoc interesse quidam putant, quod adulterium in nuptam, stuprum in viduam committitur. sed lex iulia de adulteriis hoc verbo indifferenter utitur. ${ }^{5}$

It is worth mentioning, however, that in the sources quoted further, regarding the criminal liability of slaves under the Julian statute, the term adulterium is used on a regular basis.

Referring to the subjective scope of the Julian statute, one should, first of all, cite Papinian's statement:

D. 48.5.6 pr.: Papinianus libro primo de adulteriis: Inter liberas tantum personas adulterium stuprumve passas lex iulia locum habet. quod autem ad servas pertinet, et legis aquiliae actio facile tenebit et iniuriarum quoque competit nec erit deneganda praetoria quoque actio de servo corrupto: nec propter plures actiones parcendum erit in huiusmodi crimine reo. ${ }^{6}$

So, at least in Papinian's view, the crimes provided by the statute could be committed only by free people. According to the Julian statute, adultery could only be committed by a married woman (who had the status of materfamilias or not) or by a woman cohabiting with her patron. Whereas the prerequisites of stuprum were fulfilled by sexual intercourse with a virgin or a widow (having the status of materfamilias). ${ }^{7}$ The term materfamilias used in lex Iulia meant not only a married woman, but also a widow ${ }^{8}$ and it referred to the women of good morals whose attribute was honestas. ${ }^{9}$ The Roman law scholars expressed the opinion that the term adulterium was applied to any intercourse with a woman who was in any

4 D. Stolarek, Ustawa julijska ..., p. 220.

5 "Modestinus, Distinctions, Book 9: Some people think that there is this difference between 'debauchment' and 'adultery', that adultery is committed against a married woman, debauchment against a widow, but the lex Iulia on adultery uses this word indifferently".

6 "Papinian, Adulterers, Book 1: The lex Iulia applies only between free persons who have suffered adultery or stuprum. But as far as female slaves are concerned, an action under the lex Aquilia will readily apply and that for injuria is also competent, nor must the praetorian action for the corruption of a slave be refused; nor shall someone accused of this kind of offence be spared because of the many actions [possible against him]".

7 D. Stolarek, Quasi adultera. Rozważania na gruncie Lex Iulia de Adulteriis Coercendis, „Roczniki Nauk Prawnych” 2010, vol. 20(2), pp. 136-137.

8 D.48.5.11 pr.: Papinianus libro secundo de adulteriis: Mater autem familias significatur non tantum nupta, sed etiam vidua.

9 D. Stolarek, Adultera w świetle Lex Iulia de adulteriis coercendis, Lublin 2012, p. 17. 
relationship with a man, including a relationship prohibited by law, such as incestuous one..$^{10}$ As to the possibility of accusing the man of adultery, Papinian said:

D.48.5.12.4: Papinianus, libro singulari de adulteris: Adulterii reum intra quinque annos continuos a die criminis admissi defuncta quoque muliere postulari posse palam est. ${ }^{11}$

While referring to the status of men under the Julian statute, it should be pointed out that the prevailing view in the literature is that from the point of view of lex Iulia, the status of a man was irrelevant for the qualification of action as adultery. ${ }^{12}$ However, it is necessary to consider whether the status of a man was only relevant to the qualification of the act of a woman as adulterium committed with that man, or whether it was relevant to the possibility of a man being charged. Thus, whether the question of the status libertatis of a man as a co-perpetrator of the adulterium was, or became important over time, allowing the initiation of a criminal trial also against the slave.

The purpose of these considerations is therefore to answer the question whether the slave may have been accused of adultery in a criminal trial or whether the slave was only a subject to the jurisdiction exercised by the owner under dominica potestas. It is difficult to answer this question on the basis of testimonies contained in the sources analyzed below. Sources directly or indirectly related to this issue are arranged in a certain sequence. Papinian's quoted opinion shows that the Julian statute was applicable only to free people who have committed the crime of adultery or fornication. However, Ulpian speaks clearly: servos quoque adulterii posse accusari nulla dubitatio est. ${ }^{13}$ In his opinion, there is no doubt that a slave can be accused of adultery. Moreover, Ulpian mentions the slave accused of adultery when discussing the practice of torturing the slaves:

D. 48.5.28 pr.: Ulpianus libro tertio de adulteriis: Si postulaverit accusator, ut quaestio habeatur de servo adulterii accusato, sive voluit ipse interesse sive noluit, iubent iudices eum servum aestimari, et ubi aestimaverint, tantam pecuniam et alterum tantum eum, qui nomen eius servi detulerit, ei ad quem ea res pertinet dare iubebunt. ${ }^{14}$

${ }^{10}$ M. Zabłocka, Początki przedawnienia ścigania przestępstw $w$ rzymskim prawie karnym, „Zeszyty Naukowe Uniwersytetu Rzeszowskiego” 2018, no. 101, pp. 178-189.

11 "It is clear that a man charged with adultery can be prosecuted within the five years following the date of the offence being committed, even though the woman is dead".

12 D. Stolarek, Adultera ..., p. 197. See T.A.J. McGinn, Prostitution, Sexuality and the Law in Ancient Rome, New York 1998, p. 144.

13 "Ulpian, Adulteries, Book 3: There is no doubt that slaves also can be accused of adultery".

14 "Ulpian, Adulteries, Book 3: If an accuser demands that an interrogation [under torture] be made of a slave accused of adultery, whether he himself has wished to be present or not, the judges [shall] order that slave to be valued, and when they have valued him, they shall order the man who has named the slave in his accusation to convey to him to whom this matter pertains as much money [as the slave is worth] and as much again". 
D. 48.5.28.16: Notandum est, quod capite quidem novo cavetur, si servus adulterii accusetur et accusator quaestionem in eo haberi velit, duplum pretium domino praestari lex iubet, at hic simplum. ${ }^{15}$

The cited texts of Ulpian were already the subject of scholarly analysis regarding the criminal liability of slaves on the basis of lex Iulia.${ }^{16}$ The key question in this context is whether the Julian statute explicitly recognized the slave as a potential perpetrator of the adulterium, or whether the liability of the slaves developed later, and if so, as a consequence of what kind of circumstances.

When analyzing the quoted statements of both Papinian and Ulpian, one should first of all pay attention to the fact that slaves, at the time when the Julian statute was established, were not subject to state justice courts. Roman criminal law for a long time did not recognize slaves as a subject of public law offences. Slaves were punished for crimes by their owners as a result of the domestic judiciary (iudicium domesticum).${ }^{17}$ The owners of slaves had been entitled to ius vitae ac necis since archaic times. ${ }^{18}$ On the other hand, the subjectivity of slaves as perpetrators of public crimes began to take shape only from the beginning of the $1^{\text {st }}$ century C.E. ${ }^{19}$ The gradual development of their liability may be indicated by Senatus consultum from 20 C.E. ordering the treatment of slaves in criminal proceedings as free people. ${ }^{20}$ Venuleius Saturninus talked about this decree in his monograph on public criminal proceedings, saying:

D. 48.2.12.3: Si servus reus postulabitur, eadem observanda sunt, quae si liber esset, ex senatus consulto Cotta et Messala consulibus. ${ }^{21}$

Such heterogeneity of the views could have its origin in not yet established position of the slave and could occur naturally in the period of shaping their criminal subjectivity. For this reason, it is rather doubtful that lex Iulia directly regulated the criminal liability of slaves. ${ }^{22}$ In addition to the process of determining their

15 "Attention should be paid to what is provided in chapter nine [of the statute] if a slave be accused of adultery and the accuser wishes torture to be applied to him; the statute [in general] requires double his value to be paid to the master, but in this case only the single [amount]".

16 A. Tarwacka, Rozwód Nerona i Oktawii, czyli nowa Lukrecja, „Zeszyty Prawnicze UKSW” 2009, no. 9.1, pp. 71-84; K. Stolarski, Prawnokarne regulacje dotyczace niewolników w Lex Iulia de adulteriis coercendis z 18 roku p.n.e., [in:] Culpa et poena. Z dziejów prawa karnego, ed. M. Mikuła, Kraków 2009, pp. 15-25.

17 See Th. Mommsen, Römisches Strafrecht, Leipzig 1899, p. 926.

18 M. Jońca, Parricidium w prawie rzymskim, Lublin 2008, p. 178.

19 O.F. Robinson, The Criminal Law of Ancient Rome, Baltimore 1995, p. 216.

20 W. Litewski, Rzymski proces karny, Kraków 2003, p. 83.

21 "If a slave be cited as accused, the same procedures shall be observed as if he were a freeman in accordance with the Senatus consultum given in the consulship of Cotta and Messala".

${ }^{22}$ However, in the criminal trials used slave testimonies, although they were never referred to as testes. As in W. Litewski, op. cit., p. 94. There is also an abundant source of information about torture 
criminal liability, attention should also be paid to changes that have taken place in the area of Roman criminal jurisdiction. Crimes provided by the Julian statute were within the jurisdiction of the permanent tribunal - quaestio de adulteriis. ${ }^{23}$ Quaestiones perpetue, jury tribunals, began to be created from the half of the $2^{\text {nd }}$ century B.C., replacing the iudicia populi and quaestiones extraordinariae. The first such tribunal was created on the basis of lex Calpurnia de repetundis in 149 B.C. ${ }^{24}$ In the scholarly literature, the disadvantages of the quaestiones system are indicated. One of the disadvantages was that the tribunal could not assess the crime that was not penalized by the statute which was establishing particular tribunal. ${ }^{25}$ For the purposes of this analysis, this means that if lex Iulia did not impose criminal liability for the act committed by a slave, then in the trial before the quaestio de adulteriis his accusation was impossible. Thus, not only the establishing of criminal subjectivity of slaves, but also the development of the system of criminal justice influenced the formation of slave liability based on the Julian statute. Already in the time of August, the extraordinary process (cognitio extra ordinem) started to develop and marginalized importance of the quaestiones perpetue. ${ }^{26}$

Assuming that over time slaves also become liable under lex Iulia, it is worth to consider, whether slaves of both sexes were subjects to this liability. As for the male slave, the matter seems obvious. However, the question naturally arises, whether adultery could have been committed by a free woman having intimate intercourse with a female slave. This seemingly simple matter, however, seems to be quite complex. There is a well-established view in Roman law science that the status of a woman, as a criterion of criminal liability for crimes punished by the Julian statute, caused that she could not violate this law by having sex with a female slave. ${ }^{27}$ The already mentioned Papinian wrote that in the case of female slaves complaints were used: actio legis Aquiliae, actio iniuriarum, actio servi corrupti. However, some terminological consideration should be added to the above. Modestinus noticed that servis legatis etiam ancillas deberi quidam putant, quasi commune nomen utrumque sexum contineat. ${ }^{28}$ Ulpian uses the term servus in the texts cited above. However, only when adultery is considered heterosexual, then it should be assumed

of slaves in criminal proceedings instituted for crimes criminalized by the Julian Act. Regarding the testimony of slaves in criminal proceedings, see E. Loska, Kilka uwag na temat zeznań niewolników w procesie karnym, „Zeszyty Naukowe KUL”2017, no. 3, pp. 449-464.

${ }^{23}$ K. Amielańczyk, Crimina legitima w rzymskim prawie publicznym, Lublin 2013, p. 278.

24 A. Chmiel, Ustrój rzymskich organów jurysdykcyjnych w sprawach karnych, „Studia Prawnoustrojowe" 2011, vol. 12, p. 52.

${ }^{25}$ Ibidem, p. 53.

${ }^{26}$ Ibidem, p. 54; R.A. Bauman, Crime and Punishment in Ancient Rome, London - New York 2004, p. 50.

${ }^{27}$ K. Amielańczyk, op. cit., p. 282.

${ }^{28}$ D. 50.16.101.3: „Modestinus, Distinctions, Book 9: Some people think that when slaves are bequeathed, female slaves ought to be included since a single name covers both sexes". 
that Ulpian uses the term servus in reference to a man. If it is assumed that the adulterium could be committed by a married woman through sexual contact with a female slave, then, in that case, one should consider the criminal liability of the female slave. However, this hypothesis does not appear in the scholarly literature, which is probably the result of the lack of sufficient sources concerning this issue.

As a side note, with respect to the liability of female slaves, it is also worth paying attention to the regulations contained in two texts quoted by Th. Mommsen. ${ }^{29}$ The first one is the constitution of the Emperors Diocletian and Maximian from 291 C.E. ${ }^{30}$ It contains the guidelines for imposing infamy in the case of maintaining sexual contact with female slaves. The content of this constitution shows that, in this case, the man was not a subject to infamy. However, the above-cited excerpt from Justinian's Code clearly indicates that Roman public law was not indifferent to the relationship of free men with female slaves. Besides, there are no grounds to state anything about the female slave's criminal liability. However, men having sexual contact with female slaves certainly did not incur criminal liability. Another source indicated by Th. Mommsen is Paulus' statement from the collection of Pauli Sententiae:

PS. 2.26.16: Ancillarum sane stuprum, nisi deteriores fiant, aut per eas ad dominam adfectet, citra noxam habetur.

From Paulus' testimony, it should be understood that in relation to female slaves one can speak only about the delictual liability of a person who, having sex with a slave girl, caused harm to her owner, thereby reducing the value of the female slave, or when such an attitude was directed against the owner himself. The jurist's position therefore matches Papinian's view cited above.

Moving on to the analysis of other available sources, one should point out an interesting decision comprised in the constitution of Emperors Diocletian and Maximian from 293 C.E., which also touches the issue of the slave's criminal liability for adultery. ${ }^{31}$ The constitution deals with the procedural issues when the accused of adultery pleads in defense. From the content of the imperial constitution, it fol-

29 Th. Mommsen, op. cit., pp. 691-692.

${ }^{30}$ C. 9.9.24: Etsi libidine intemperatae cupiditatis ex actorum lectione exarsisse te cognitum est, tamen cum ancillam comprehendisse et non liberam stuprasse detectum sit, ex huiusmodi sententia gravatam potius opinionem tuam quam infamia adflictam esse manifestum est.

${ }^{31}$ C. 9.9.25: Quoniam alexandrum, qui in crimen vocatur, etiam praescriptionem esse pollicitum eo nomine, quod accusator uxorem post comprehensum adulterium penes se habuisse videatur, et de statu suo agere nunc velle perspeximus, ita ordo quaestionis dirimendus videtur, ut in primis quidem de statu alexandri quaeratur, ita ut, si eum liberum esse adhibita audientia deprehenderis, praescriptionis ei obiciendae facias potestatem: sin vero eundem servum esse cognoveris, remotis praescriptionis impedimentis in adulterium crimen protinus debebis inquirere ac, si eum detectum in eo flagitio esse perspexeris, poenam decernere, quam in adulterii crimen legum sanctio statuit. 
lows that in such a case the defendant's status libertatis should first be examined and if it is established that he is a slave, then the procedural obstacle caused by the allegation will be removed, which will allow the slave to be tried and sentenced in the event that he is found guilty of the alleged crime.

Further sources are a good addition to the above-quoted statement of Ulpian, because their content shows that there is no doubt about the possibility of accusing the slave of adultery. It is therefore important to pay attention to Marcianus statement:

D. 48.5.34 pr.: Marcianus libro primo de publicis iudiciis: Si quis adulterium a servo suo commissum dicat in eam, quam uxorem habuit, divus pius rescripsit accusare potius mulierem eum debere, quam in praeiudicium eius servum suum torquere. 32

Marcianus explicitly refers to the situation when the slave is accused of committing adultery. This is indicated by the used wording: "[...] if someone accuses of committing adultery on his slave, with the one who was his wife". In the following part of his statement, Marcianus presents the following view:

D. 48.5.34.1: Si quis adulterum non dimiserit, sed retinuerit, forsan filium in noverca vel etiam libertum vel servum in uxore, ex sententia legis tenetur, quamvis verbis non continetur. quae autem retinetur, punitur. sed si dimissam reduxerit, verbis non tenetur: sed tamen dicendum est, ut teneatur, ne fraus fiat..$^{33}$

This statement does not directly refer to the key issue discussed in this article, but it is a helpful clue in determining whether the criminal liability of slaves was regulated in lex Iulia, or whether it was formed later, through the gradual formation of the subjectivity of slaves as perpetrators of public law crimes. Attention should be paid to the phrase used in this statement: Si quis adulterum non dimiserit ... ex sententia legis tenetur, quamvis verbis non continetur. The jurist writes about the situation in which the victim of adultery "does not send the adulterer but stops him" (e.g., a slave) and is, therefore, punished in accordance with the statute, even if the statute does not mention who was detained. The jurist's remark may thus indicate the primary lack of regulation in lex Iulia of the issue of criminal liability of slaves for adultery.

32 "Marcianus, Criminal Proceedings, Book 1: The deified Pius wrote in a rescript that if anyone states that a slave of his own has committed adultery with her who was his wife, he ought rather to accuse the woman than to torture his slave as a preliminary to an action against her".

33 "If anyone does not let go an adulterer but keeps him [by him], as it might be a son [caught] with his stepmother or a freedman or a slave with his wife, he is punished according to the spirit of the law, even though by its letter [the adulterer] who is retained is not covered. Again, if a [husband] remarries a [wife] dismissed [the house], he is not liable under the words [of the statute], but it must be said that he is to be liable to avoid the possibility of fraud". 
Guidance regarding the slaves' criminal liability for adultery can be found in Paulus' writings. The jurist, while speaking about the husband's rights (also having the status of filius familias) towards his wife caught in flagranti with an adulterer, mentions a number of people who could be killed by the harmed husband without being accused of murder. Paulus says that the husband is allowed to kill an adulterer if he is a slave:

Coll. 4.3.2: Ergo secundam leges viro etiam filiofamilias permittitur domi suae deprehensum adulterum interficere servum, et eum qui auctoramento rogatus est ad gladium, vel etiam illum qui operas suas, ut cum bestiis pugnaret, locavit. ${ }^{34}$

It does not mean, however, that Paulus admitted the possibility of accusing the slave of adultery. In addition, the jurist states:

Coll. 4.12.1: Permittitur patri tam adoptivo, quam naturali, adulterum cum filia cuiusque dignitatis domi suae vel generi sui deprehensum sua manu occidere. ${ }^{35}$

In turn, Paulus' next statement reads as follows:

Coll. 4.12.3: Maritus in adulterio deprehensos non alios, quam infames et eos, qui corpore quaestum faciunt, servos etiam et libertas excepta uxore, quam prohibetur, occidere potest. ${ }^{36}$

However, this does not also prejudge the possibility of accusing a slave of adultery in a public criminal trial. It should be borne in mind that the owners were entitled to punish their slaves for the crimes they committed within the scope of their dominica potestas. Paulus' quoted views concern the rights of the adulterer's father and the harmed husband to take advantage of their ius occidendi. ${ }^{37}$ Nevertheless, it should be noted that Paulus allowed the applicability of ius occidendi against a slave who had committed adultery. Since ius occidendi was a right, the question arises: Could the father or the harmed husband be able to prosecute the slave if he did not exercise his right? For if the adulterer was not killed under ius occidendi, criminal proceedings could be instituted against him. It seems that the quoted

34 "Thus, the husband, even if he is a filius familias, is permitted, according to the Statutes, to kill a man whom he has taken in adultery in his house, if the adulterer is a slave, a paid gladiator, or one who has let out his services to fight with wild beasts". Translation of the cited fragments of Collatio Legum Mosaicarum et Romanarum is given after the English edition: Mosaicarum et Romanarum Legum Collatio, transl. M. Hyamson, Oxford 1913.

35 "An adoptive or a natural father is permitted to kill with his own hand the adulterer taken with his daughter in his house or in that of his son-in-law, whatever be the adulterer's rank".

36 "The husband has the right to kill the adulterer taken in the act only when he belongs to one of the following classes: Persons branded with infamy, public performers, slaves and freedmen. The wife is excepted by an express prohibition".

${ }^{37}$ More broadly, see K. Amielańczyk, op. cit., pp. 118-123. 
opinions of Ulpian and Marcianus allow to give an affirmative answer. Similarly, Macer's testimony shows that a harmed husband had the right to deprive a life of an adult caught in adultery in his home, who would be slave:

D. 48.5.25 pr.: Macer libro primo publicorum: Marito quoque adulterum uxoris suae occidere permittitur, sed non quemlibet, ut patri: nam hac lege cavetur, ut liceat viro deprehensum domi suae (non etiam soceri) in adulterio uxoris occidere eum, qui leno fuerit quive artem ludicram ante fecerit in scaenam saltandi cantandive causa prodierit iudiciove publico damnatus neque in integrum restitutus erit, quive libertus eius mariti uxorisve, patris matris, filii filiae utrius eorum fuerit (nec interest, proprius cuius eorum an cum alio communis fuerit) quive servus erit. ${ }^{38}$

Despite the considerable amount of testimonies, especially those inserted by Justinian compilers in the Digest, regarding issues related to ius occidendi on the basis of lex Iulia, we do not find among them any that would explain procedural issues in the event of non-exercise of this right in relation to the slave.

An interesting view was expressed by Papinian in the $1^{\text {st }}$ Book of the monograph on adultery. The jurist writes as follows:

D. 48.3.2 pr.: Si servus capitali crimine postuletur, lege publicorum cavetur, ut sistendum vel a domino vel ab extero satisdato promittatur: quod si non defendatur, in vincula publica coici iubetur, ut ex vinculis causam dicat. ${ }^{39}$

Since adulterium and stuprum were offences of public law and their prosecution was carried out in a public trial, one may wonder whether the view expressed by Papinian as a general norm was also updated in the application of the Julian statute. It is also significant that Papinian's view was taken from his monograph on adultery. Papinian's message is about accusing a slave of committing a crime punishable by death. However, the death penalty for adulterers was only used since the time of Constantine the Great ${ }^{40}$ - a contrario, at the time when Papinian was active, death penalty was not imposed on adulterers. There is no evidence from which it would appear that in the case of slaves such punishment was imposed in Papinian's time. Paulus mentions the death penalty for a stuprum committed with

38 "Macer, Criminal Proceedings, Book 1: A husband also is permitted to kill his wife's adulterer, but not, as a father is, whoever it may be; for it is provided by this statute that a husband is permitted to kill a man whom he catches in adultery with his wife in his own house (not also [in that] of his father-in-law) if the [paramour] is a pimp or if he was previously an actor or performed on the stage as a dancer or singer or if he has been condemned in criminal proceedings and is not yet restored to his former status, or if he is a freedman of the husband or wife or of the father, mother, son, or daughter of either of them (and it is of no consequence whether he was the sole property of one of them or was owned jointly with someone else) or if he is a slave". More broadly, see K. Amielańczyk, op. cit., p. 120.

39 "If a slave be accused on a capital charge, the statute on criminal proceedings provides that bail must be pledged for his appearance either by his master or by another; but if he is not defended, he is required to be thrown into a public prison so as to plead his case in chains".

${ }^{40}$ K. Amielańczyk, op. cit., p. 294. 
a man: Qui masculum liberum invitum stupraverit, capite punitur. ${ }^{41}$ In contrast, the death penalty was imposed in the late Empire. ${ }^{42}$

In turn, the aforementioned Venuleius Saturninus in the $2^{\text {nd }}$ Book of the monography on public criminal proceedings expressed the view that slaves can become accused under all statutes, except of those which were explicitly enumerated by the jurist or those which provide the penalties that do not apply to the slave, such as relegation. Importantly, lex Iulia was not mentioned by the jurist in the exclusion catalog:

D. 48.2.12.4: Omnibus autem legibus servi rei fiunt excepta lege iulia de vi privata, quia ea lege damnati partis tertiae bonorum publicatione puniuntur, quae poena in servum non cadit. idemque dicendum est in ceteris legibus, quibus pecuniaria poena irrogatur vel etiam capitis, quae servorum poenis non convenit, sicuti relegatio. item nec lex pompeia parricidii, quoniam caput primum eos adprehendit, qui parentes cognatosve aut patronos occiderint: quae in servos, quantum ad verba pertinet, non cadunt: sed cum natura communis est, similiter et in eos animadvertetur. item cornelia iniuriarum servum non debere recipi reum cornelius sulla auctor fuit: sed durior ei poena extra ordinem imminebit. . $^{33}$

Hence, it can be concluded that the jurist's statement is not explicit, but nevertheless indicates the admissibility of the slave's charge of adultery.

The constitution of Emperor Constantine on punishment for adultery committed with a slave, provided in the title De mulieribus quae se servis propriis junxerunt belonging to the $9^{\text {th }}$ Book of the Theodosian Code, also provides some clues. ${ }^{44}$ According to it, the relationship of a free woman with a slave was prohibited by law. The constitution states that anyone could bring charges of adultery. Both the

${ }^{41}$ PS. 2.26.12 = Coll. 5.2.1: "He who debauches a free male against his will shall suffer capital punishment".

42 As in K. Amielańczyk, op. cit., p. 294.

43 "Slaves are liable to be charged under all laws except the lex Iulia de vi privata, because those condemned under that law are punished by the confiscation of one third of they property, a penalty which does not apply to a slave. The same must be said of other laws under which a pecuniary penalty is inflicted, or even a capital penalty, such as relegation, which is not suitable as a penalty for a slave. Again, the lex Pompeia on parricide is not [applicable] since its first chapter covers those who have killed their parents, blood relations, or patrons; so far as the words go these do not apply to slaves, but when the essence of the case is the same, a similar punishment will be imposed on them also. Again, under the [lex] Cornelia on injuria, Cornelius Sulla was the authority [for saying] that a slave should not be accused; but a more severe penalty extra ordinem will threaten him". See R.A. Bauman, op. cit., p. 117.

${ }^{44}$ C.Th 9.9.1.6.: Post legem enim hoc committentes morte punimus. qui vero ex lege disiuncti clam denuo convenerint, congressus vetitos renovantes, hi servorum indicio vel speculantis officii vel etiam proximorum delatione convicti poenam similem sustinebunt. dat. iv. kal. iun. serdicae, constantino a. vii. et constantio c coss. interpretatio. si qua ingenua mulier servo proprio se occulte miscuerit, capitaliter puniatur. servus etiam, qui in adulterio dominae convictus fuerit, ignibus exuratur. in potestate habeat huius modi crimen quicumque* voluerit accusare... 
woman and the slave were punished with death. The phrase servus etiam, qui in adulterio dominae convictus fuerit, ignibus exuratur was used here. It does not mean upon the content of the constitution that the accusation could only be brought against adulterers. It is therefore justified to conclude that the accusation of a slave was also admissible.

An excellent illustration of the problem is the divorce of Emperor Nero and Octavia. ${ }^{45}$ Briefly, the facts were as follows. One of Octavia's servants reported her alleged relationship with the slave Eucareus. Eucareus was accused of adultery, and as noted by A. Tarwacka, it should be concluded from Tacitus that a criminal trial was carried out in this case. ${ }^{46}$ Tacitus writes: "Her waiting-maids, in pursuance of the scheme, were examined under torture; and, although a few were forced by their agony into making groundless admissions, the greater number steadfastly maintained the honour of their mistress". ${ }^{47}$ Failed to prove guilt of Octavia. Still, as Tacitus writes, "she was removed, however, first under colour of a civil divorce, [...]. A little later, she was banished to Campania and put under military supervision". ${ }^{48}$ Then Nero brought Octavia to Rome, where he accused her again of adultery, urging Prefect Anicetus to plead guilty. Suetonius writes about this matter rather laconic:

He soon grew tired of living with Octavia, and when his friends took him to task, replied that "she ought to be content with the insignia of wifehood". Presently after several vain attempts to strangle her, he divorced her on the ground of barrenness, and when the people took it ill and openly reproached him, he banished her besides; and finally he had her put to death on a charge of adultery. ${ }^{49}$

It should be noted that Suetonius' testimony concerns only the re-accusation of Octavia - an alleged intercourse with Anicetus. The accounts of both historians do not, of course, answer the question about the possibility of accusing the slave of adultery. However, they are certainly a valuable hint.

45 This story, i.a. in the context of the slave's criminal liability for adultery, presented by A. Tarwacka (Rozwód Nerona..., pp. 71-81). Citing Tacitus, she discussed the divorce of Nero with his first wife, Octavia. On the basis of the facts described, the author asked whether the relationship with the slave was considered adultery. She also quoted Papinian's statement (D. 48.5.6 pr.) and Ulpian's view (D. 48.2.5). See also R.A. Bauman, op. cit., p. 89.

46 A. Tarwacka, Rozwód Nerona..., pp. 75-76.

47 Tacitus, Ann 14.60, [in:] Tacitus, Annals. Books 13-16, transl. J. Jackson, Cambridge 1937.

48 Ibidem.

49 Suet. Nero 35, [in:] Suetonius, Lives of the Caesars, transl. J.C. Rolfe, vol. 2, Cambridge 1914. 


\section{CONCLUSION}

Analysis of the presented sources, both legal and literary, certainly does not allow to answer negatively on the question of the possibility of accusing the slave of adultery. However, it is difficult to state unequivocally, upon a rather scarce source material, that under the statute of Iulia de adulteriis coercendis, slaves could be accused of committing adulterium on an equal basis with the free people. However, the gradual development of slave subjectivity as perpetrators of crimes prosecuted by the state justice system should be taken into account. While in the period in which lex Iulia was promulgated, they were not subjects of the state's jurisdiction, but from the $1^{\text {st }}$ century A.D. Roman criminal law began to recognize slaves as perpetrators of public law crimes. The changes in the area of criminal jurisdiction were also significant in this respect. An extraordinary procedure - cognitio extra ordinem - began to develop from the times of August, which, without the disadvantages of quaestiones perpetue, slowly began to displace them.

In conclusion, the accusation of a slave for adultery in the early period of application of the Julian statute was inadmissible, but as a result of changes in Roman public criminal law, consisting in expanding the scope of perpetrators of public law crimes, it became possible according to the view expressed by Ulpian: servos quoque adulterii posse accusari nulla dubitatio est. It should be noted that the male slaves were subject to criminal liability for adultery, while the lack of source information does not make it possible to determine whether the female slaves were also liable. It is known that in relation to female slaves, their owners had legal protection based on complaints: actio legis Aquiliae, actio iniuriarum, actio servi corrupti, submitted against a person who, having sexual intercourse with a female slave, harmed her owner - be it by lowering the value of the slave or by insulting the owner (actio iniuriarum). However, as to the criminal liability of female slaves, it can only be hypothesized upon the meaning of the word servus and considering adultery from the perspective of homosexual relationships.

\section{REFERENCES}

Amielańczyk K., Crimina legitima w rzymskim prawie publicznym, Lublin 2013.

Bauman R.A., Crime and Punishment in Ancient Rome, London - New York 2004.

Chmiel A., Ustrój rzymskich organów jurysdykcyjnych w sprawach karnych, „Studia Prawnoustrojowe" 2011, vol. 12.

Collatio Legum Mosaicarum et Romanarum is given after the English edition: Mosaicarum et Romanarum Legum Collatio, transl. M. Hyamson, Oxford 1913.

Jońca M., Parricidium w prawie rzymskim, Lublin 2008.

Kowalski H., Omnia sunt alia non crimina, sed maledicta - oskarżenia o nieobyczajność w rzymskich procesach karnych pierwszej połowy I wieku p.n.e. (na podstawie mów Cycerona), [in:] Contra 
leges et bonos mores. Przestępstwa obyczajowe w starożytnej Grecji i Rzymie, eds. H. Kowalski, M. Kuryłowicz, Lublin 2005.

Langlands R., Sexual Morality in Ancient Rome, New York 2006.

Litewski W., Rzymski proces karny, Kraków 2003.

Loska E., Kilka uwag na temat zeznań niewolników w procesie karnym, „Zeszyty Naukowe KUL” 2017, no. 3.

McGinn T.A.J., Concubinage and the Lex Iulia on Adultery, "Transactions of the American Philological Association” 1991, vol. 121, DOI: https://doi.org/10.2307/284457.

McGinn T.A.J., Prostitution, Sexuality and the Law in Ancient Rome, New York 1998.

Mommsen Th., Römisches Strafrecht, Leipzig 1899.

Rizzelli G., Stuprum e adulterium nella cultura augustea e la lex Iulia de adulteriis (Pap. 1 adult. D. 48.5.6.1 e Mod. 9 diff. D.50.16.101 pr.), "Bullettino dell'istituto di Diritto Romano" 1987, no. 90.

Robinson O.F., The Criminal Law of Ancient Rome, Baltimore 1995.

Stolarek D., Adultera w świetle Lex Iulia de adulteriis coercendis, Lublin 2012.

Stolarek D., Quasi adultera. Rozważania na gruncie Lex Iulia de Adulteriis Coercendis, „Roczniki Nauk Prawnych" 2010, vol. 20(2).

Stolarek D., Ustawa julijska o karaniu za cudzołóstwa 5 tytuł 48 księgi Digestów. Tekst, tlumaczenie, komentarz, „Zeszyty Prawnicze” 2012, no. 12.1,

DOI: https://doi.org/10.21697/zp.2012.12.1.12.

Stolarski K., Prawnokarne regulacje dotyczace niewolników $w$ Lex Iulia de adulteriis coercendis z 18 roku p.n.e., [in:] Culpa et poena. Z dziejów prawa karnego, ed. M. Mikuła, Kraków 2009.

Suetonius, Lives of the Caesars, transl. J.C. Rolfe, vol. 2, Cambridge 1914.

Tacitus, Annals. Books 13-16, transl. J. Jackson, Cambridge 1937.

Tarwacka A., Rozwód Nerona i Oktawii, czyli nowa Lukrecja, „Zeszyty Prawnicze UKSW”2009, no. 9.1 .

The Digest of Justinian, transl. A. Watson, Philadelphia 1985.

Zabłocka M., Poczatki przedawnienia ścigania przestępstw w rzymskim prawie karnym, „Zeszyty Naukowe Uniwersytetu Rzeszowskiego" 2018, no. 101,

DOI: https://doi.org/10.15584/znurprawo.2018.22.13.

Zabłocka M., Zmiany w ustawach matżeńskich Augusta za panowania dynastii julijsko-klaudyjskiej, „Prawo Kanoniczne” 1987, no. 1-2,

DOI: https://doi.org/10.21697/pk.1987.30.1-2.10.

\section{ABSTRAKT}

Celem niniejszego artykułu jest próba udzielenia odpowiedzi na pytanie, czy niewolnik lub niewolnica ponosili odpowiedzialność karną za adulterium. Uchwalona w 18 r. p.n.e. ustawa Lex Iulia de adulteriis coercendis, należąca do tzw. ustawodawstwa małżeńskiego Augusta, wprowadziła pojęcie adulterium pojmowane jako przestępstwo prawa publicznego. Ustawa ta była bardzo szeroko komentowana przez jurystów rzymskich. Jednakże w dostępnych źródłach prawniczych zauważa się rozbieżne poglądy dotyczące odpowiedzialności karnej niewolników na gruncie tej ustawy. W literaturze poświęconej ustawie julijskiej zagadnienie to nie zostało dostatecznie przeanalizowane.

Słowa kluczowe: odpowiedzialność karna; ustawa julijska; prawo publiczne; Lex Iulia de adulteriis coercendis; crimina legitima; niewolnik; niewolnica 